\title{
RELATIONSHIP BETWEEN STORED SPERMATOZOA AND THE UTERINE EPITHELIUM IN THE PIPISTRELLE BAT (PIPISTRELLUS PIPISTRELLUS)
}

\author{
P. A. RAGEY AND D. M. POTTS* \\ Wellcome Institute of Comparative Physiology, Zoological Society of London, \\ Regent's Park, N.W.1, and *School of Anatomy, University of Cambridge
}

(Received 2nd April 1969)

\begin{abstract}
Summary. Spermatozoa distend the uterus of the overwintering pipistrelle bat and their relationship with the uterine epithelium has been examined. The epithelium actively secretes PAS-positive material and spermatozoa are found orientated with their heads directed towards it over large areas. Electron microscopy has revealed that microvilli originating from the epithelial cells are commonly in contact with the cell membrane of the spermatozoa. It is suggested that this contact may constitute one of the pathways by which nutrient material from the endometrium is transferred to the stored spermatozoa and may account, in part, for the prolonged survival of the spermatozoa in this species. The relationship between spermatozoa and their storage organs is briefly reviewed.
\end{abstract}

\section{INTRODUCTION}

Vespertilionid bats of temperate zones generally copulate during the autumn and spermatozoa are stored in the uterus until the following spring, when ovulation and fertilization occur. In addition, spermatozoa are stored in the epididymides of the males and copulation is also reported to occur during the winter (Wimsatt, 1945; Gilbert \& Stebbings, 1958) and the spring (Moffatt, 1922; Aubert, 1963). Folk (1940) and Wimsatt (1944) demonstrated that stored spermatozoa retain their fertilizing capacity for at least 5 months in the North American species Eptesicus fuscus and Myotis lucifugus, by isolating females as soon as possible after copulation and showing the presence of fertilized eggs and conceptuses in the following spring. Kleiman \& Racey (1970) repeated these experiments with European noctules (Nyctalus noctula) which produced live young from spermatozoa stored for approximately $6 \frac{1}{2}$ months.

Harrison Matthews (1937) has shown that, in the two British rhinolophids, Rhinolophus ferrum-equinum and $R$. hipposideros, spermatozoa are stored during the winter in the Fallopian tubes, uterus and vagina. The vagina is enlarged

* Present address: International Planned Parenthood Federation, 18-20 Lower Regent Street, London, S.W.1. 
and occluded by a hyaline plug of male origin, which prevents further copulation and persists until ovulation and corpus luteum formation have occurred in the spring. This provides indirect evidence that the ovum is fertilized by one of the spermatozoa stored in the upper genital tract for at least 5 months. The vagina of the pipistrelle is similarly occluded by a plug (Gourrier, 1924) formed by massive keratinization of the vaginal epithelium. This must serve to confine the spermatozoa in the uterus and probably also prevents further copulation.

Several authors (Kohlbrugge, 1913; Courrier, 1921; Nakano, 1928; Redenz, 1929) have pointed out that stored spermatozoa are arranged with their heads towards the wall of the endometrium. Austin \& Bishop (1959) examined $P$. pipistrellus and $R$. ferrum-equinum and confirmed Kohlbrugge's (1913) assertion that spermatozoa entered the mucosa of the Fallopian tubes, and Wimsatt, Krutzsch \& Napolitano (1966) have subsequently shown an electron micrograph of a spermatozoon embedded in a uterine epithelial cell of $M$. lucifugus.

Courrier (1921) and Reeder (1939) have described uterine secretions in bats and have suggested that these may be important in maintaining the spermatozoa during the period of storage. Nakano (1928) demonstrated the presence of glycogen in Vespertilio abramus throughout hibernation and its absence at other times. He related the production of glycogen to the arrangement of the spermatozoa with their heads towards the uterine epithelium and suggested that it served to nourish the spermatozoa. Schwab (1952), however, could not detect glycogen in the uterus of the inseminated noctule, Nyctalus noctula.

The fine structure of the epididymal spermatozoa of $M$. lucifugus and $E$. fuscus has been described by Fawcett \& Ito (1965). Wimsatt et al. (1966) subsequently found only minor differences between the fine structure of uterine and epididymal spermatozoa of $M$. lucifugus, and suggested that uterine environmental factors were most important for sperm survival.

The present work attempts to examine more closely the relationship between the stored spermatozoa and the uterine epithelium in the pipistrelle.

\section{MATERIALS AND METHODS}

Inseminated parous and nulliparous females were caught while feeding in flight by means of mist nets, or in their hibernacula in country churches between October 1967 and January 1968. Uninseminated parous females, which had given birth in captivity during the summer of 1967 and had been denied the opportunity to mate, together with juvenile uninseminated females born in the wild and captured subsequently, were used for comparison.

Bats were killed by decapitation. For electron microscopy, the intact uterus was quickly removed using a dissecting microscope, fixed in cacodylatebuffered glutaraldehyde for $4 \mathrm{hr}$, and washed in buffer for at least $24 \mathrm{hr}$. The uterus was post-fixed in Dalton's fluid for $\frac{1}{2} \mathrm{hr}$, dehydrated and infiltrated with celloidin and sectioned at $80 \mu$ on a sledge microtome. Serial celloidin sections were embedded in Araldite and observed with the light microscope (Potts, 1965). Well preserved areas of uterus and adjacent spermatozoa were selected 
for resectioning on the ultramicrotome. Sections stained with toluidine blue and azure blue were observed by light microscopy. Sections for electron microscopy were stained with uranyl acetate and lead citrate.

In addition, uteri were fixed in cold Bouin's fluid and embedded in paraffin wax. Sections were stained with the McManus modification of the periodic acid-Schiff (PAS) reaction, with and without haematoxylin counterstaining, and Best's method for the demonstration of glycogen. In both cases, adjacent sections were incubated with a $1 \%$ solution of malt diastase before staining.

\section{OBSERVATIONS}

\section{Uninseminated uterus}

Following fixation and embedding, each horn of the Y-shaped bicornuate uterus is approximately $1 \mathrm{~mm}$ in diameter. The uterine lumen is small and partially occluded and the uterine columnar epithelial cells measure approximately $15 \mu$ high $\times 5 \mu$ wide. There is a loose submucosa and a thick myometrium (approximately $110 \mu$ ) so that the whole wall of the uterus is about 150 to $200 \mu$ wide. The nuclei of the uterine epithelial cells are centrally placed and the endoplasmic reticulum is poorly developed although there are numerous mitochondria, especially in the basal region. The cytoplasm is rich in RNA, lipid droplets are found in the apical zone and clumps of free glycogen particles appear in the areas of cytoplasm devoid of organelles.

\section{Inseminated uterus}

This is T-shaped and massively distended with spermatozoa (Pl. 1, Fig. 1) so that each horn measures up to 3 to $4 \mathrm{~mm}$ in diameter. In unfixed material, semen can be seen as a viscous opaque mass through the uterine wall which is very delicate. If punctured, the fluid which exudes shows a swirling movement under the microscope, which is characteristic of concentrated, highly motile spermatozoa (see Mann, 1964).

Following fixation and embedding, the inseminated uterus is 2 to $3 \mathrm{~mm}$ in diameter. Electron micrographs show that the wall of the uterus is only 25 to $50 \mu$ in thickness. The uterine epithelial cells (measuring about $5 \mu$ high and $7 \mu$ wide) are elongated along the circumference of the uterus and overlap one another. There are interdigitating cell processes between neighbouring cells (Pl. 1, Fig. 3) which are especially prominent in the area proximal to the desmosomes and unite the cells at their luminal surface, although they sometimes involve the whole of the lateral wall of the endometrial cells down to the basement membrane. The epithelium of the inseminated uterus differs from that of the uninseminated uterus in the size and distribution of the microvilli which are more irregular and show some branched forms. The microvilli have a fibrous core and contain electron-dense material common to the endometrial cells. Microvacuoles were not seen in the microvilli. In both inseminated and uninseminated uteri, a very small proportion of epithelial cells are ciliated.

The basement membrane under the epithelial cells shows slight irregularities in the uninseminated specimens but is flattened in the inseminated series. Stromal cells, consisting of fibroblasts and occasional white blood cells, are 
found in the uninseminated uteri but in the inseminated specimens the epithelial cells rest directly on the myometrial cells.

\section{Sperm-uterus relationship}

In sections of both inseminated and uninseminated uteri stained by the PAS method, the luminal border of the endometrium is invariably strongly positive (Pl. 1, Fig. 2). Processing for light microscopy often causes the spermatozoa to separate from the uterine epithelium, but their orientation with their heads towards the PAS-positive material is retained in the crypts of the uterine glands. Such crypts are more commonly present at the distal end of each uterine horn (Pl. 1, Fig. 1).

Sections treated with diastase showed that some of the PAS-positive material is labile and this was confirmed as glycogen by Best's carmine method. Such glycogen as can be demonstrated, however, occurs intermittently in the luminal border of the epithelial cells and accounts for only a proportion of the PASpositive material. Clumps of epithelial cells are often found sloughed off into the lumen of the uterus, and whereas the PAS-positive reaction of the uterine epithelium is in general confined to its luminal border, with granules sometimes occurring within the cells, the entire contents of these sloughed cells stain positively. In addition, many PAS-positive granules are visible in the sperm mass in the lumen of the uterus.

In both the 80- $\mu$ celloidin sections embedded in Araldite and the sections cut and stained from them, the spermatozoa are orientated with their heads in close approximation to the luminal border of some areas of the uterine epithelium (Pl. 2, Fig. 4). Electron micrographs of this area show that endometrial microvilli are in direct contact with the cell membrane of the head piece of the spermatozoa (Pl. 1, Fig. 3; Pl. 2, Fig. 5) and, in some instances, extend from either side of the subjacent epithelium towards such a head piece. Contact between microvilli and spermatozoa is not, however, limited to the head piece, for in micrographs showing spermatozoa in various levels of section in the crypts of the uterine glands, contact between microvilli and the head, mid, principal and end pieces is also visible.

\section{DISCUSSION}

Although the uteri of most species of hibernating vespertilionid bats of temperate zones are thought to contain spermatozoa during the winter, massive distension of the uterus has only been described in the case of the pipistrelle (Redenz, 1929) and the noctule, Nyctalus noctula (Schwab, 1952). The average density of spermatozoa from the uterus of the noctule was found by Schwab to be $6 \times 10^{6} / \mu \mathrm{l}$ and represents one of the highest recorded concentrations of spermatozoa in mammalian semen (Mann, 1964). Little is known, however, of the factors affecting the prolonged survival of the stored spermatozoa. Redenz (1929) suggested that high $\mathrm{pCO}_{2}$ levels produced by sperm metabolism and crowding in the uterus favoured survival. The effect of high $\mathrm{pCO}_{2}$ in reducing the motility of spermatozoa in vitro has subsequently been demonstrated (reviewed in Mann, 1964). Hartman (1933) conjectured that the low body 
PLATE 1

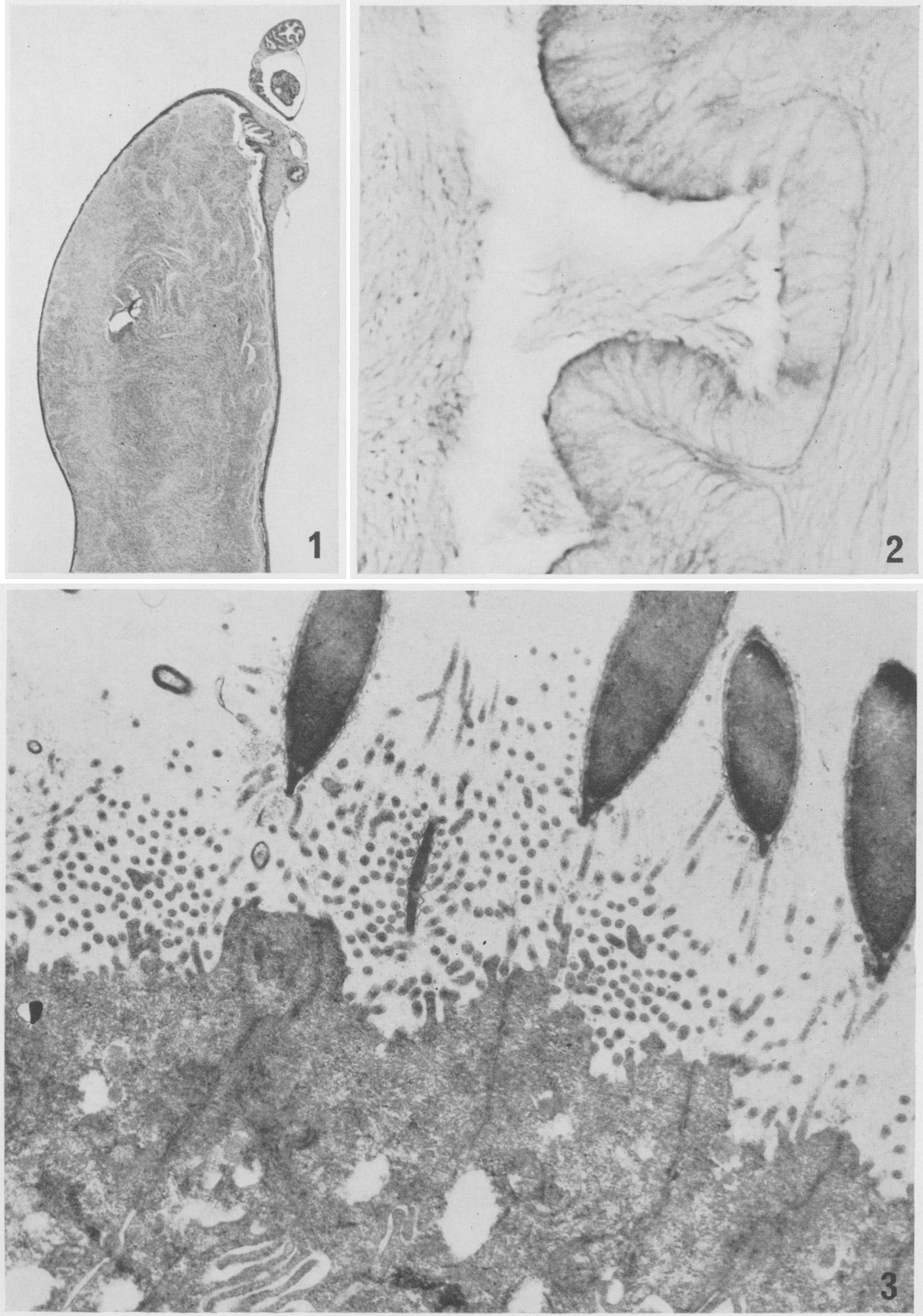

Sperm-filled uterus of the pipistrelle.

FIG. 1. Distension with spermatozoa. $\mathrm{H} \& \mathrm{E}, \times 16$.

FIG. 2. PAS, no counterstain. $\times 750$.

FIG. 3. Contact between microvilli and spermatozoa, especially around the single head piece cut transversely. $\times 18,500$. 
PI.XTE, 2

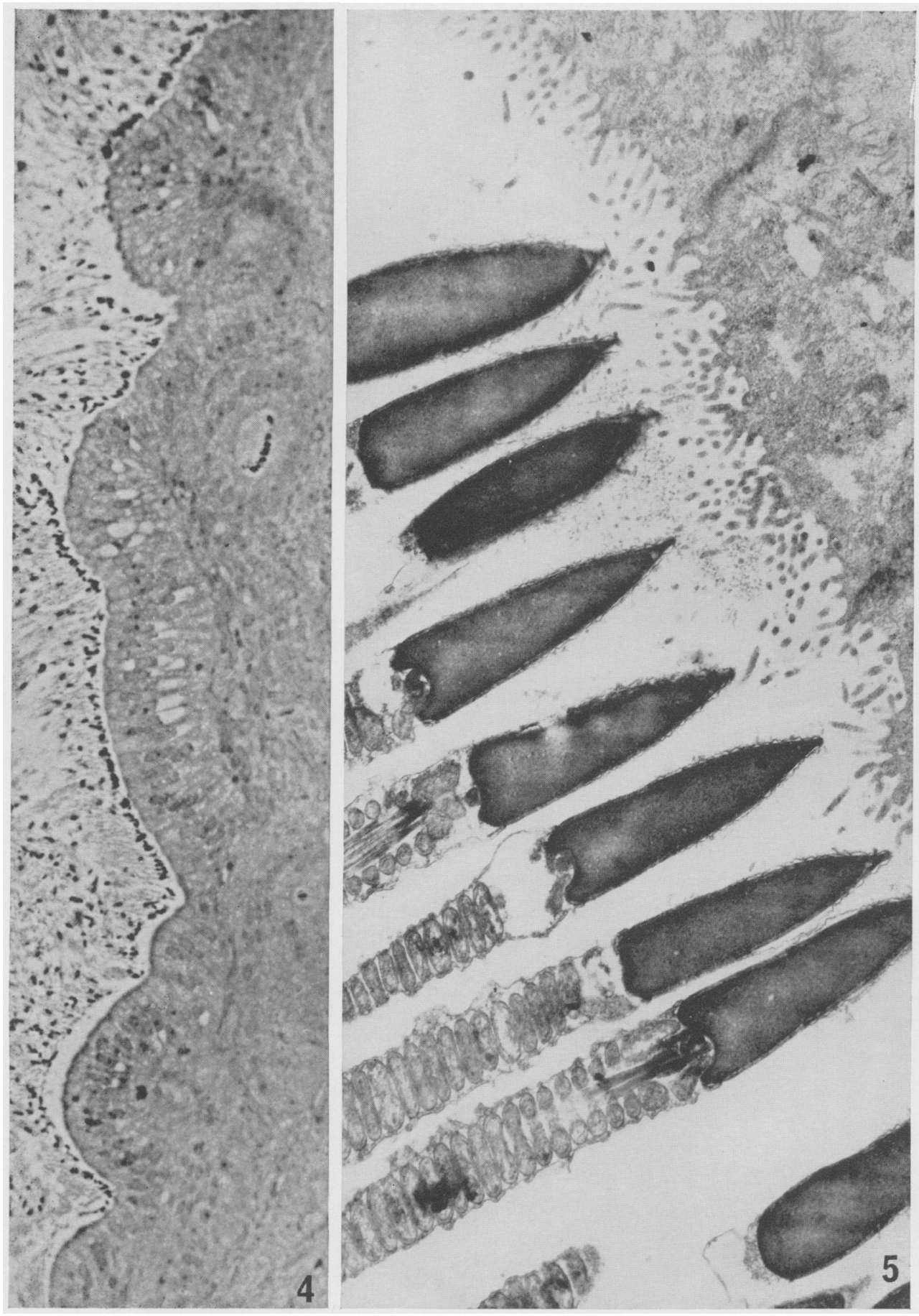

Sperm-filled uterus of the pipistrelle.

Fig. 4. Spermatozoa lined up to the uterine epithelium and in the crypt of a uterine gland. Aralditc section, $\times 450$.

FIG. 5. Part of Fig. 4 at higher magnification. $\times 18,500$. 
temperature of hibernating bats reduced sperm motility and this, in turn, aided survival but it has since become clear that bats do not maintain a low body temperature for as long a period as was formerly believed but often wake up, fly and feed during the winter (Ransome, 1968).

Bat spermatozoa have been little studied in vitro but the data available (Schwab, 1952; Henriet, 1966) indicate that they do not survive any longer in such conditions than the spermatozoa of other mammals. It seems unlikely, therefore, that the seminal plasma of the bat contains enough nutrient material for prolonged survival. In addition, Fawcett \& Ito (1965) and Wimsatt et al. (1966) found no evidence that bat spermatozoa contain a greater store of endogenous substrates than the spermatozoa of other species. The endometrium must, therefore, supply the essential nutrients and the present work has shown it to be a highly active secretory gland. It stains very strongly with PAS, a reaction which is specific for 1-2 glycol links (Hotchkiss, 1948) which are, in turn, associated with compounds likely to be of nutrient value to the spermatozoa. The latter are orientated with their heads towards the PAS-positive material. This could be explained as a chemotaxic effect of the endometrium on the spermatozoa but other stimuli, such as higher $\mathrm{pO}_{2}$ or lower $\mathrm{pCO}_{2}$ at the endometrium compared with the centre of the sperm mass, cannot be excluded. An alternative explanation may be that the spermatozoa become orientated towards the wall of the uterus by a mechanical sorting effect from a mass of highly motile gametes. Stickiness of the cell membrane and microvilli might also account for contact between them.

Microvilli containing granular material are seen in contact with the cell membrane of the spermatozoa and it is tempting to suggest that the transfer of nutrients may occur directly from the endometrium to the spermatozoa along these, as well as by the more obvious route of secretion into the uterine lumen and subsequent absorption by the spermatozoa. The number of spermatozoa in contact with the microvilli must, however, represent a small proportion of the total present in the uterus. The degree of motility of the intra-uterine spermatozoa is difficult to establish although Schwab (1952) suggested that the high density of spermatozoa in the uterus of the noctule rendered motility impossible. Ciliated epithelial cells occur only rarely in mammalian uteri, and the presence of such cells in the uterus of the pipistrelle suggests that they may be involved together with muscular movements of the whole uterus in stirring the contents. In this way, the secretions of the epithelium may be circulated into the sperm mass and likewise spermatozoa within the uterus may change places with those at the epithelium.

The orientation of stored spermatozoa, with their heads towards the luminal border of their storage organs, is not an uncommon phenomenon and examples can be found in most classes of vertebrates. Stolk (1950) showed such a relationship in the ovary of the cyprinodont fish, Lebistes, where the spermatozoa are found in crypts orientated towards an immature egg. In the dog-fish, Scylliorhinus canicula, Metten (1939) demonstrated that spermatozoa were stored in the region of the oviducal gland which secretes shell substance and he suggested that this secretion nourished the spermatozoa. Fox (1956) shows a crypt full of orientated spermatozoa in the wall of the oviduct of the garter 
snake, Thamnophis sirtalis, and a similar arrangement in the lizard, Anolis carolinensis (Fox, 1963). Saint-Girons (1962) found that the epithelium of the seminal receptacles of the chameleon is PAS-positive, like the uterus of the pipistrelle. Large numbers of spermatozoa were found in these structures in animals isolated for several months, and fertilized eggs were recovered. Orientated spermatozoa have been demonstrated in the glands of the uterovaginal junction of the domestic hen (Bobr, Lorenz \& Ogasawara, 1964) and, in the uterine glands of the bitch (Doak, Hall \& Dale, 1967). A more detailed examination of the relationship between spermatozoa and their storage organs may reveal more intimate contact, as has been demonstrated in the pipistrelle. Whether such an arrangement is involved specifically in sperm nutrition will, however, only be determined by experiment. It is interesting in this context to note that Hamner \& Sojka (1968) recently reported that for rabbit spermatozoa to become capacitated, they require intimate contact with the uterine and oviducal epithelium.

\section{ACKNOWLEDGMENTS}

We would like to thank Mrs P. A. Racey for help in capturing the bats and Mrs S. Barton for expert technical assistance. We are also grateful to the World Health Organization (P.A.R.) and the Medical Research Council (D.M.P.) for financial support.

\section{REFERENCES}

Aubert, A. (1963) Observation sur l'accouplement des cheiroptères. Acta theriol. 6, 300.

Austin, C. R. \& Bishop, M. W. H. (1959) Presence of spermatozoa in the uterine-tube mucosa of bats. 7. Endocr. 18, viii.

Bobr, L. W., Lorenz, F. W. \& Ogasawara, F. X. (1964) Distribution of spermatozoa in the oviduct and fertility in domestic birds. 1. Residence sites of spermatozoa in fowl oviducts. F. Reprod. Fert. 8, 39.

Courrier, R. (1921) Sur le rôle physiologique des sécrétions utérine et tubaire chez la chauve-souris hibernante. C.r. Séanc. Soc. Biol. 84, 572.

Courrier, R. (1924) Le cycle sexuel chez la femelle des mammifères. Etude de la phase folliculaire. Archs Biol., Paris, 34, 369.

DoAk, R. L., HALl, A. \& Dale, H. E. (1967) Longevity of spermatozoa in the reproductive tract of the bitch. F. Reprod. Fert. 13, 51.

Fawcetr, D. W. \& ITo, S. (1965) The fine structure of bat spermatozoa. Am. 7. Anat. 116, 567.

FoLK, G. E. (1940) The longevity of sperm in the female bat. Anat. Rec. 76, 103.

Fox, W. (1956) Seminal receptacles of snakes. Anat. Rec. 124, 579.

Fox, W. (1963) Special tubules for sperm storage in female lizards. Nature, Lond. 198, 500.

Gilbert, O. \& Stebbings, R. E. (1958) Winter roosts of bats in West Suffolk. Proc. zool. Soc. Lond. 131, 329.

Hamner, C. E. \& SojKA, N. J. (1968) Requirements for capacitation of rabbit sperm. Nature, Lond. 220, 1042.

Harrison Matrhews, L. (1937) The female sexual cycle in the British horseshoe bats Rhinolophus ferrum-equinum insulanus Barrett-Hamilton and R. hipposideros minutus Montagu. Trans. zool. Soc. Lond. 23, 224.

Hartman, G. G. (1933) On the survival of spermatozoa in the female genital tract of the bat. Q. Rev. Biol. 8, 185 .

HeNRIET, L. (1966) Essai de conservation prolongée des spermatozotdes par l'action des cellules utérines. In: Report for 1966 of Centre d'Insémination Artificielle de Lovenjoel, p. 27. Université de Louvain, Belgium.

HoтchкIss, R. D. (1948) A microchemical reaction resulting in the staining of polysaccharide structures in fixed tissue preparations. Archs Biochem. 16, 131. 
KLEIman, D. G. \& RaceY, P. A. (1970) Observations on noctule bats (Nyctalus noctula) breeding in captivity. Lynx, 10, (in press).

KohlarugGe, J. H. F. (1913) Die verbreitung der Spermatozoiden im weiblichen Körper und im befruchten Ei. Arch. EntwMech. Org. 35, 165.

MANN, T. (1964) The biochemistry of semen and of the male reproductive tract. Methuen, London.

Metren, H. (1939) Studies on the reproduction of the dogfish. Phil. Trans. R. Soc. Ser. B, 230, 217.

Moffart, G. B. (1922) The habits of the long-eared bat. Ir. Nat. 31, 105.

NAKaNo, O. (1928) Über die verteilung des Glycogens bei den zyklischen veränderungen in den Geschlechtsorganen der Fledermaus und über die Nahrungsaufnahme der Spermien im dem wieblichen Geschlechswege. Folia Anat. jap. 6, 777.

Potrs, D. M. (1965) A method for locating specific histological features for electron microscopy. $\mathcal{F l} R$. microsc. Soc. 85, 97.

Ransome, R. D. (1968) The distribution of the greater horseshoe bat, Rhinolophus ferrum-equinum during hibernation, in relation to environmental factors. F. Zool., Lond. 154, 77.

Redenz, E. (1929) Das verhalten der Säugetierspermatozoen zwischen Begattung und Befruchtung. Z. Zellforsch. mikrosk. Anat. 9, 734.

REeder, E. M. (1939) Cytology of the reproductive tract of the female bat Myotis lucifugus lucifugus. $\mathcal{F}$. Morph. 64, 431.

Saint-Girons, H. (1962) Présence de réceptacle séminaux chez les caméléons. Beaufortia, 9, 165.

ScHWAB, H. (1952) Beobachtungen über die Begattung und die Spermakonservierung in den Geschlechtsorganen bei weiblichen Fledermäusen. Z. mikrosk.-anat. Forsch. 58, 326.

SToLk, A. (1950) Histo-endocrinological analysis of the gestation phenomena in the cyprinodont Lebistes reticulatus (trans.). Thesis, University of Utrecht.

WimsatT, W. A. (1944) Further studies on the survival of spermatozoa in the female reproductive tract of the bat. Anat. Rec. 88, 193.

WimsatT, W. A. (1945) Notes on breeding behaviour, pregnancy and parturition in some vespertilionid bats of the Eastern United States. F. Mammal. 26, 23.

Wimsatt, W. A., Krutzsch, P. H. \& Napoltrano, L. (1966) Studies on sperm survival mechanisms in the female reproductive tract of hibernating bats. 1. Cytology and ultrastructure of intra-uterine spermatozoa in Myotis lucifugus. Am. F. Anat. 119, 25. 